\title{
Influence of industrial solid waste addition on properties of soil-cement bricks
}

\section{(Influência da adição de resíduo sólido industrial nas propriedades de tijolos solo-cimento)}

\author{
F. B. Siqueira, M. C. Amaral, R. A. Bou-Issa, J. N. F. Holanda* \\ Grupo de Materiais Cerâmicos, LAMAV-CCT, Universidade Estadual do Norte Fluminense Darcy Ribeiro, \\ Av. Alberto Lamego, 2000, Campos dos Goytacazes, RJ, Brazil 28013-602 \\ fabriciobagli@bol.com.br,holanda@uenf.br*
}

\begin{abstract}
The reuse of pollutant solid wastes produced in distinct industrial activities (avian eggshell waste and welding flux slag waste) as a source of alternative raw material for producing soil-cement bricks for civil construction was investigated. Soil-cement bricks containing up to $30 \mathrm{wt} \%$ of industrial solid waste were uniaxially pressed and cured for 28 days. Special emphasis is given on the influence of solid waste addition on the technical properties (as such volumetric shrinkage, water absorption, bulk density, durability, and compressive strength), microstructure and mineral phases of soil-cement bricks. Microstructural evolution was evaluated via confocal microscopy. The experimental results showed that the solid wastes behave as charge material and influenced both technical properties and microstructure of the soil-cement bricks. It was found that up to $15 \mathrm{wt} \%$ of welding flux slag waste and up to $30 \mathrm{wt} \%$ of avian eggshell waste could be added into the soil-cement bricks for use as building material.
\end{abstract}

Keywords: solid waste, soil-cement brick, microstructure.

Resumo

O aproveitamento de resíduos sólidos poluentes produzidos em distintas atividades industriais (resíduo de casca de ovo galináceo e resíduo de escória de soldagem) como fonte de matérias-primas alternativas para produção de tijolos solo-cimento para construção civil foi investigado. Tijolos solo-cimento contendo até 30\% em massa de resíduo sólido industrial foram preparados por prensagem uniaxial e curados durante 28 dias. Ênfase especial é dada à influência da adição dos resíduos sólidos sobre as propriedades técnicas (retração volumétrica, absorção de água, densidade aparente, durabilidade e resistência à compressão simples) e microestrutura dos tijolos solo-cimento. A evolução microestrutural foi avaliada via microscopia confocal. Os resultados experimentais mostraram que os resíduos sólidos industriais se comportam como um material de carga, bem como influenciam ambas as propriedades técnicas e microestrutura dos tijolos solo-cimento. Foi estabelecido que até 15\% em massa de residuo de escória de fluxo de soldagem e até $30 \%$ em massa de resíduo de casca de ovo galináceo poderiam ser adicionados em tijolos solocimento para uso como material de construção.

Palavras-chave: residuo sólido, tijolo solo-cimento, microestrutura.

\section{INTRODUCTION}

There is at present an increasing interest on the reuse of solid waste materials as renewable raw materials applied to the building materials field $[1,2]$. In fact, the traditional raw materials can be replaced by solid wastes, resulting usually in considerable economical and environmental benefits. The food processing industry produces several waste materials, including eggshell. The eggshell waste (EW) is a non-biodegradable solid material composed essentially of calcium carbonate $(\sim 94 \mathrm{wt} \%)$ and organic matter $(\sim 4$ $w t \%)$ [3]. In the metal-mechanical industry the submerged arc welding process is widely used for the manufacturing of heavy equipments [4]. The flux used in submerged arc welding is partially melted and forms a liquid protective slag layer. This solidified slag is also considered a non- biodegradable solid waste material, and hereafter referred to as welding flux slag waste (WFSW) [5]. Both industrial solid waste materials create significant environmental problems. In addition, these solid wastes are mainly disposed in private waste sites, causing economical and environmental impacts. For this reason, there is high interest in new technological solutions for the reuse of both industrial solid waste materials.

The soil-cement bricks have been widely recognized as an important building material mainly in developing countries [6]. The soil-cement bricks present economic and technical advantages as compared with fired clay bricks, such as low-cost, improved technical properties, and elimination of the firing step, which has high energy consumption [7]. In recent years, several solid wastes have been investigated as possible new additive to soil-cement bricks [8-12], 
exhibiting promising results. However, despite the building material industry is highly promising for absorption of large volume of industrial solid wastes, little attention has been given to the reuse of EW and WFSW for obtaining soil-cement bricks $[13,14]$. This work focuses on the incorporation of solid wastes (EW and WSFW) into a soil-cement brick body as partial replacement of conventional raw materials. The influence of the solid waste addition on the technical properties and microstructure of the soil-cement bricks was investigated.

\section{EXPERIMENTAL PROCEDURE}

Seven soil-cement brick mixtures containing up to 30 $\mathrm{wt} \%$ of solid waste were prepared (Table I). In this work, the Portland cement was partially replaced with EW, while sandy soil was partially replaced with WFSW. A traditional soil-cement brick mixture (soil:cement - 9:1) was used as a reference. The EW sample, provided by a local food company, was dried at room temperature $\left(\sim 23{ }^{\circ} \mathrm{C}\right)$ for one week, and then dried at $110{ }^{\circ} \mathrm{C}$ for $24 \mathrm{~h}$ in an oven. The WFSW sample collected in a local welding plant in form of rods was dried at $110^{\circ} \mathrm{C}$ for $24 \mathrm{~h}$ in an oven. Then, both solid wastes were crushed into powder and sieved through a 100 mesh (150 $\mu \mathrm{m}$ ASTM) sieve. Commercial Portland cement (CP III-40RS) and sandy soil were used. Table II gives the chemical composition of the raw materials used. Table III gives the mineral phases present in the raw materials. The soil/cement/solid waste mixtures (Table I) were homogenized in a laboratory mixer, and then humidified with $16 \mathrm{wt} \%$ of water relative to the total mass. Cylindrical soil-cement pieces (37 $\mathrm{mm}$ in diameter and $56 \mathrm{~mm}$ in height) were prepared by uniaxial pressing, and then cured for 28 days in a humid chamber $\left(95 \%\right.$ humidity at $\left.24{ }^{\circ} \mathrm{C}\right)$.

The following technical properties were determined: volumetric shrinkage, water absorption, bulk density, compressive strength, and durability. Volumetric shrinkage values were evaluated from volume variations of the cylindrical pieces. The bulk density was determined according to $\mathrm{Db}=$ $\mathrm{M} / \mathrm{V}$, where $\mathrm{M}$ is the cured piece mass $(\mathrm{g})$ and $\mathrm{V}$ is the apparent volume $\left(\mathrm{cm}^{3}\right)$. Water absorption values were determined from weight differences between the as-cured and water-saturated pieces (immersed in cold water for $24 \mathrm{~h}$ ), according to NBR

Table I - Batch compositions used in experiments (g). [Tabela I - Composições das formulações usadas nos experimentos (g).]

\begin{tabular}{ccccc}
\hline Batch & Soil & Cement & EW & WFSW \\
\hline MA0 & 1080 & 120 & 0 & 0 \\
ME10 & 1080 & 108 & 12 & 0 \\
ME20 & 1080 & 96 & 24 & 0 \\
ME30 & 1080 & 84 & 36 & 0 \\
MS5 & 1026 & 120 & 0 & 54 \\
MS10 & 972 & 120 & 0 & 108 \\
MS15 & 918 & 120 & 0 & 162 \\
\hline
\end{tabular}

Table II - Chemical compositions of the raw materials (wt $\%$ ). [Tabela II - Composições químicas das matérias-primas (\% em massa).]

\begin{tabular}{ccccc}
\hline Compound & Soil & Cement & EW & WFSW \\
\hline $\mathrm{SiO}_{2}$ & 50.92 & 18.94 & 0.09 & 21.03 \\
$\mathrm{Al}_{2} \mathrm{O}_{3}$ & 33.22 & 7.14 & 0.03 & 28.32 \\
$\mathrm{Fe}_{2} \mathrm{O}_{3}$ & 7.92 & 1.22 & 0.02 & 6.23 \\
$\mathrm{CaO}$ & 0.68 & 65.38 & 50.70 & 5.32 \\
$\mathrm{TiO}_{2}$ & 1.51 & 0.53 & - & 9.51 \\
$\mathrm{~K}_{2} \mathrm{O}$ & 3.51 & 0.56 & - & - \\
$\mathrm{Na}_{2} \mathrm{O}$ & 0.01 & - & 0.19 & - \\
$\mathrm{ZrO}_{2}$ & - & - & - & 2.65 \\
$\mathrm{MnO}_{2}$ & - & - & - & 24.96 \\
$\mathrm{SO}_{3}$ & 2.05 & 3.72 & 0.57 & - \\
$\mathrm{LOI}^{*}$ & 10.83 & 2.51 & 47.80 & $1.87^{+}$ \\
\hline
\end{tabular}

*LOI - loss on ignition; + weight gain.

Table III - Mineral phases identified in the raw materials. [Tabela III - Fases minerais identificadas nas matériasprimas.]

\begin{tabular}{|c|c|}
\hline Raw material & Mineral phase \\
\hline Soil & $\begin{array}{l}\text { kaolinite }\left(\mathrm{Al}_{2} \mathrm{O}_{3} \cdot 2 \mathrm{SiO}_{2} \cdot 2 \mathrm{H}_{2} \mathrm{O}\right) \text {, quartz } \\
\left.(\mathrm{SiO})_{2}\right) \text {, gibbsite }\left(\mathrm{Al}_{2} \mathrm{O}_{3} \cdot 3 \mathrm{H}_{2} \mathrm{O}\right), \\
\text { goethite }\left(\mathrm{Fe}_{2} \mathrm{O}_{3} \cdot \mathrm{H}_{2} \mathrm{O}\right), \\
\text { mica }\end{array}$ \\
\hline Cement & $\begin{array}{l}\text { tricalcium aluminate }\left(\mathrm{C}_{3} \mathrm{~A}\right) \\
\text { tetracalcium aluminoferrite }\left(\mathrm{C}_{4} \mathrm{AF}\right) \\
\text { belite }\left(\mathrm{C}_{2} \mathrm{~S}\right) \text {, alite }\left(\mathrm{C}_{3} \mathrm{~S}\right) \text {, gypsum }\end{array}$ \\
\hline EW & calcite $\left(\mathrm{CaCO}_{3}\right)$ \\
\hline WFSW & $\begin{array}{l}\text { quartz }\left(\mathrm{SiO}_{2}\right) \text {, spinel }\left(\mathrm{MgAl}_{2} \mathrm{O}_{4}\right) \text {, } \\
\text { ferrian spinel }\left[\mathrm{Mg}(\mathrm{Al}, \mathrm{Fe})_{2} \mathrm{O}_{4}\right], \\
\text { rutile }\left(\mathrm{TiO}_{2}\right) \text {, fluorite }\left(\mathrm{CaF}_{2}\right), \\
\text { manganese oxide }\left(\mathrm{MnO}_{2}\right) \text {, cristobalite } \\
\left(\mathrm{SiO}_{2}\right)\end{array}$ \\
\hline
\end{tabular}

10836 [15]. The simple compressive strength of the cured bricks was determined using a universal testing machine at a loading rate of $1 \mathrm{~mm} / \mathrm{min}$, according to NBR 10836 [15]. The durability of the soil-cement bricks produced was determined in accordance with NBR 13554 [16]. Laser scanning microscopy was used to examine the fracture surfaces of the soil-cement based composites after 28 days of curing. The mineral phase analysis of the cured composites was done via $\mathrm{X}$-ray diffraction (XRD) by using $\mathrm{Cu}-\mathrm{K} \alpha$ radiation, angular range of $5^{\circ}<2 \theta<70^{\circ}$, and scanning speed of $1.5^{\circ}(2 \theta) /$ min. The mineral phases were identified by comparing the intensities, d-spacing, and positions of the Bragg peaks with those listed in the ICDD-JCPDS cards.

\section{RESULTS AND DISCUSSION}

XRD patterns of the soil-cement bricks incorporated with solid wastes after curing at 28 days are shown in Fig. 1. As 
expected, the reference soil-cement brick (MA0 sample) exhibited diffraction peaks that are characteristics of mineral

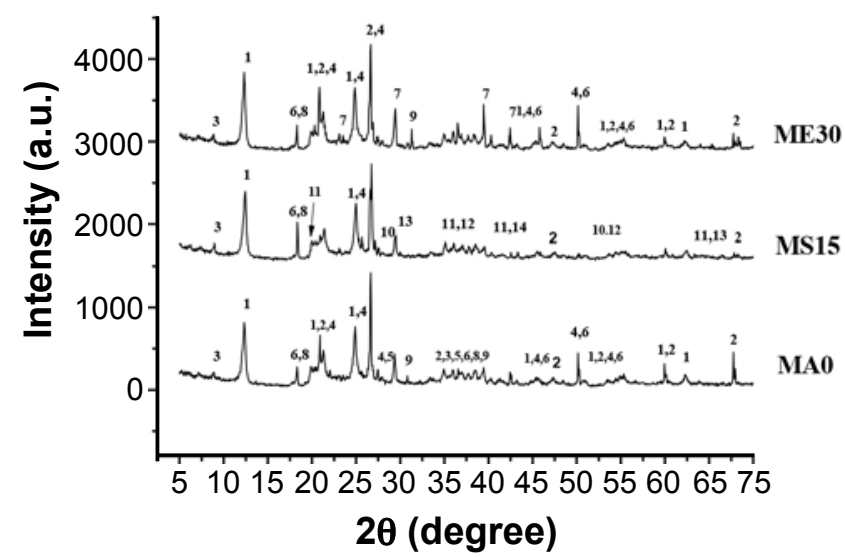

Figure 1: X-ray diffraction patterns of the cured soil-cement bricks: 1 - kaolinite, 2 - quartz, 3 - mica, 4 - calcium silicate hydrate, 5 - ettringite, 6 - portlandite, 7 - calcite, 8 - gibbsite, 9 - goethite, 10 - fluorite, 11 - spinel, 12 - rutile, 13 - ferrian spinel, and 14 manganese oxide.

[Figura 1: Difratogramas de raios $X$ de tijolos solo-cimento curados: 1 - caulinita, 2 - quartzo, 3 - mica, 4 - silicato de cálcio hidratado, 5 - etringita, 6 - portlandita, 7 - calcita, 8 - gibsita, 9 - goetita, 10 - fluorita, 11 - espinélio, 12 - rutilo, 13 - espinélio férrico e 14 - óxido de manganês.] phases linked with the soil (kaolinite, quartz, gibbsite, and goethite) and hydrated Portland cement (calcium silicate hydrate, ettringite, and portlandite). It can be seen that the incorporation of solid waste tends to modify the mineralogical behavior of the cured reference soil-cement brick. In addition, small changes in the intensities of the diffraction peaks occurred. In fact, the calcite was also detected in the soilcement composite added with EW (ME30 sample). On the other hand, the soil-cement bricks added with WFSW (MS15) presented the following additional phases: fluorite, rutile, spinel, and manganese oxide.

Fig. 2 shows the fracture surfaces of the soil-cement bricks added with solid wastes cured for 28 days. Confocal micrographs show the typical sequence of densification with increasing amounts of solid waste. The homogeneous distribution of the particles of EW and WFSW in the soilcement cementitious matrix can be observed. Note that the fracture surface of the MA0 sample (Fig. 2a) presented rough texture and capillary pores. This microstructure is typical of conventional soil-cement brick composite. When the Portland cement was partially replaced with up to $30 \mathrm{wt} \% \mathrm{EW}$ (Fig. $2 \mathrm{~b}, \mathrm{c})$, a denser fracture surface was observed. In addition, it is likely that the EW particles had a good adherence with the cementitious matrix. In a similar way, the partial replacement of soil with up to $15 \mathrm{wt} \%$ WFSW also indicated a denser microstructure (Fig. 2d-f). However, it seems that the WFSW
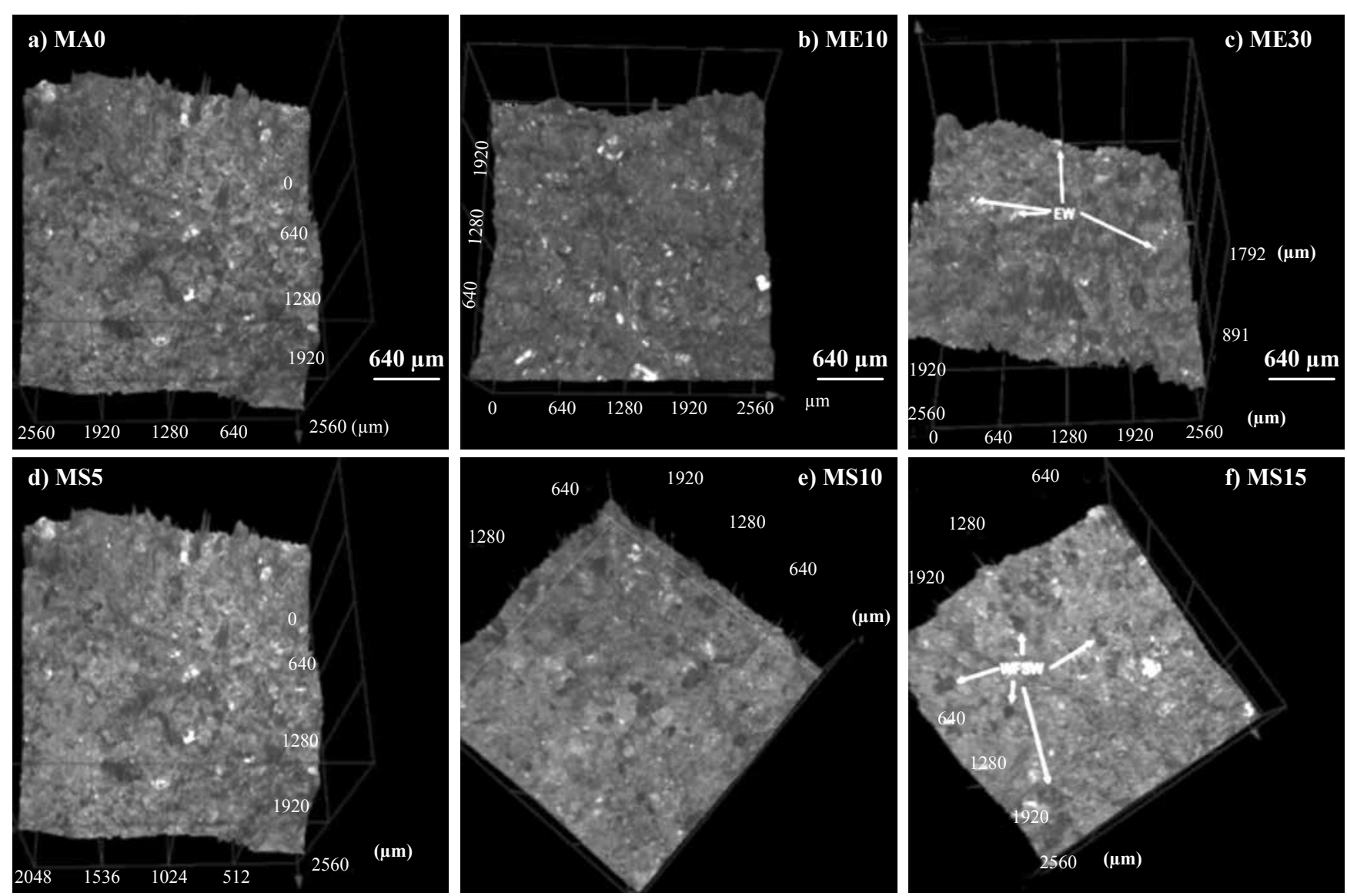

Figure 2: 3D-confocal micrographs of the cured soil-cement bricks: a) MA0; b) ME10; c) ME30; d) MS5; e) MS10; and f) MS15. [Figura 2: Micrografias de confocal - 3D dos tijolos solo-cimento curados: a) MA0; b) ME10; c) ME30; d) MS5; e) MS10; ef) MS15.] 
particles are not well attached, although the cementitious matrix is well packed. This high densification is related to the charge effect of both solid wastes, which decreases the capillary porosity of the cured soil-cement bricks.

Figs. 3 to 7 show the influence of the solid waste addition on the technical properties of the soil-cement bricks. The soil-cement brick with $0 \mathrm{wt} \%$ waste (MA0 sample, $100 \%$ soil-cement body) was used as the reference material. The volumetric shrinkage of the soil-cement bricks is shown in Fig. 3. It may be observed that all the soil-cement bricks presented low volumetric shrinkage ranging from $0.14 \%$ to $0.65 \%$. The volumetric shrinkage was found to decrease with the addition of solid waste. This effect is due to both solid wastes to be considered non-plastic materials, as such, behaves as charge material and decreases the global plasticity of the soil-cement bricks.

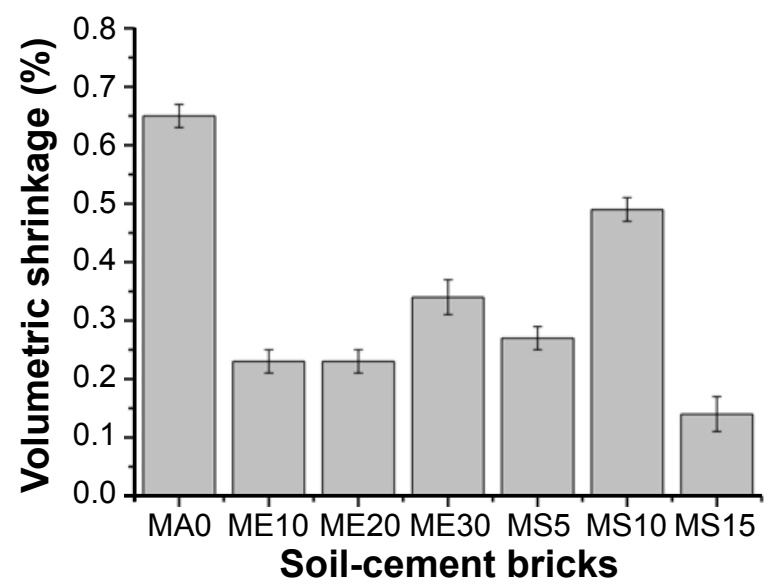

Figure 3: Effect of solid waste addition on the volumetric shrinkage of the soil-cement bricks.

[Figura 3: Efeito da adição de resíduo sólido sobre a retração volumétrica dos tijolos solo-cimento.].

Fig. 4 shows the water absorption of the soil-cement bricks. Water absorption is related to the microstructure of the soil-cement brick, and also determines the amount of open pores. It was observed that water absorption tends to decreases with the solid waste addition. This result is in agreement with microstructure (Fig. 2) and bulk density (Fig. 5). In fact, the soil-cement bricks added with the solid wastes show lower water absorption than the waste-free brick. Both solid wastes (EW and WFSW) act as a charge material (i.e., low chemical activity), and positively influences the granulometric composition of the conventional soil-cement brick. The addition of both solid wastes (EW and WFSW) decreased the amount of capillary pores and improved the packing of the soil-cement cementitious matrix. As shown in Fig 4, all soil-cement bricks added with solid waste presented values of water absorption below $20 \%$, indicating their conformity for industrial production of soil-cement bricks [17].

The compressive strength of the soil-cement bricks is shown in Fig. 6. It can be seen that the compressive strength depends on the type of added solid waste. The compressive strength of the soil-cement bricks added with up to $20 \mathrm{wt} \%$

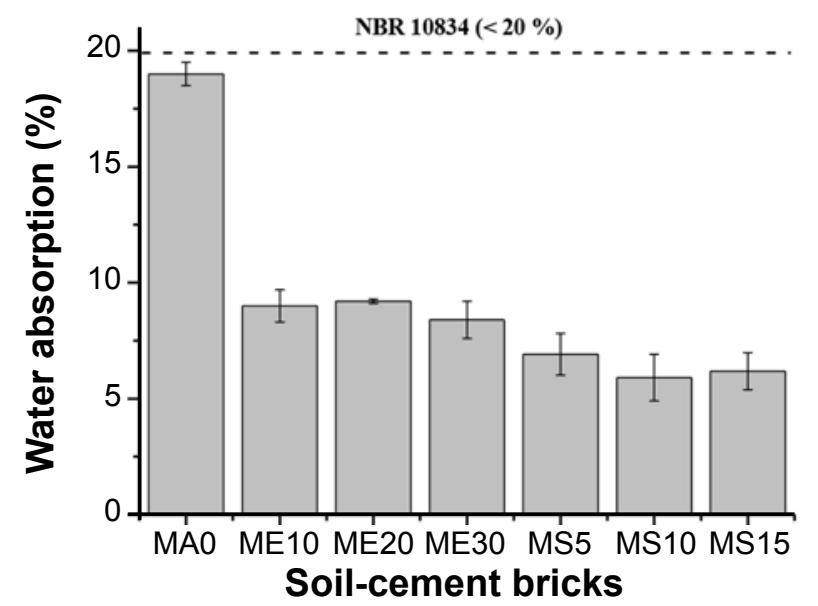

Figure 4: Effect of solid waste addition on the water absorption of the soil-cement bricks.

[Figura 4: Efeito da adição de resíduo sólido na absorção de água dos tijolos solo-cimento.]

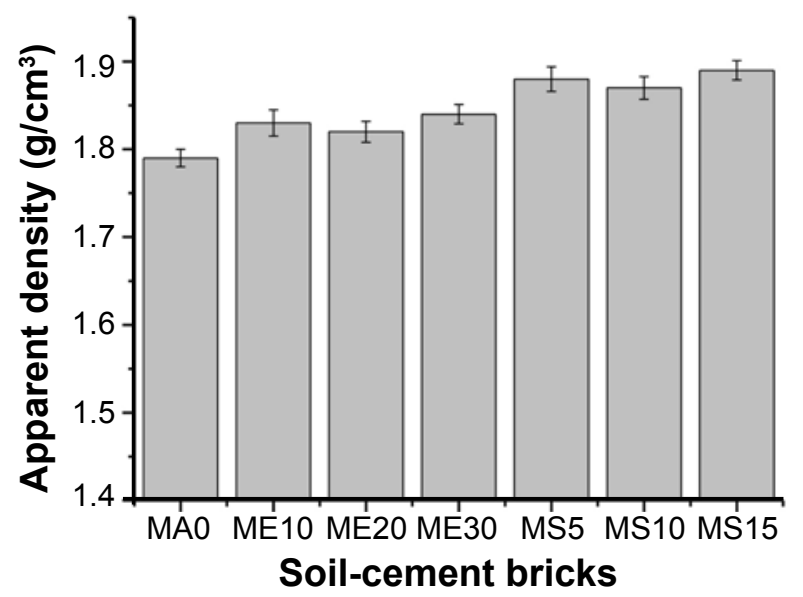

Figure 5: Effect of solid waste addition on the bulk density of the soil-cement bricks.

[Figura 5: Efeito da adição de resíduo sólido na densidade dos tijolos solo-cimento.]

EW was higher than that of the EW-free brick (MA0 sample). For addition of $30 \mathrm{wt} \% \mathrm{EW}$ (ME30 sample), a decrease in mechanical strength was observed. However, the compressive strength was very similar to that of the EW-free brick. It can be also observed in Fig. 6 that the compressive strength of the MS5, MS10 and MS15 samples decreased with the added WFSW amount. This detrimental effect on the mechanical strength of the soil-cement bricks could be explained by the lower adhesion of the WFSW particles with concomitant weakening of the cementitious matrix, despite of the reduction in open porosity (Fig. 4). The above data suggest that additions of solid waste (above $30 \mathrm{wt} \% \mathrm{EW}$ and above $15 \mathrm{wt} \% \mathrm{WFSW}$ ) into soil-cement brick mixtures should be avoided, because it impairs the mechanical strength. Despite of this, all soil-cement bricks produced presented values of compressive strength ( $\sigma \geq 2 \mathrm{MPa}$ ) [17], in conformity for use as soil-cement bricks.

The durability of the soil-cement bricks in terms of mass loss is shown in Fig. 7. Note that the introduction of solid 


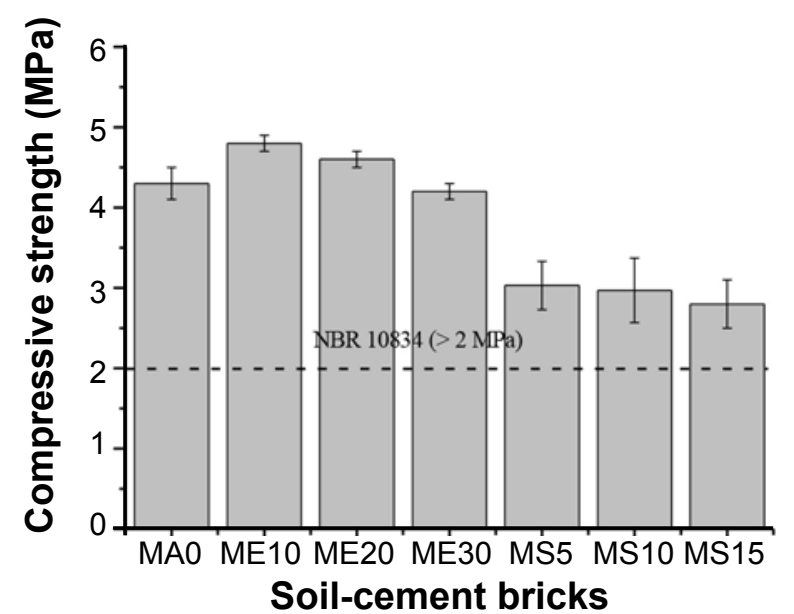

Figure 6: Effect of solid waste addition on the compressive strength of the soil-cement bricks.

[Figura 6: Efeito da adição de resíduo sólido sobre a resistência à compressão simples dos tijolos solo-cimento.]

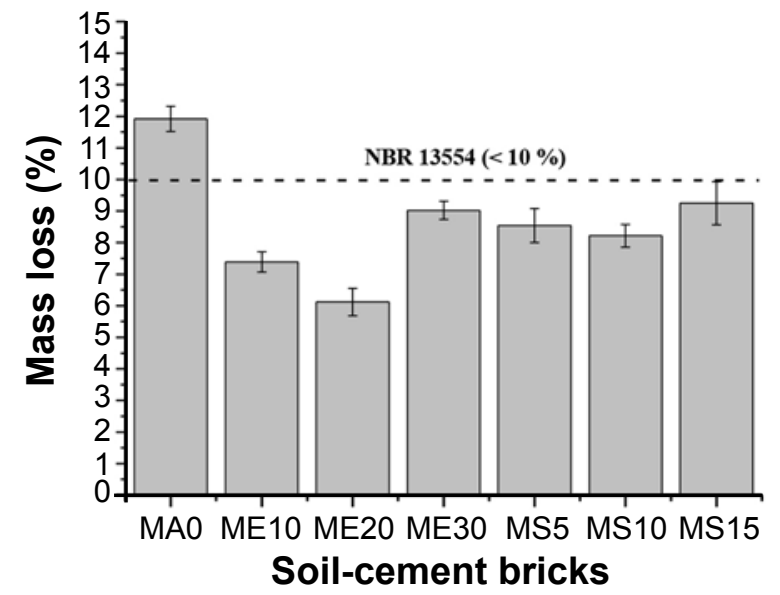

Figure 7: Effect of solid waste addition on the durability of the soil-cement bricks.

[Figura 7: Efeito da adição de resíduo sólido na durabilidade dos tijolos solo-cimento.]

waste has a beneficial effect on the durability of the soilcement bricks. The waste-added bricks presented lower mass loss. This finding was expected since the solid waste addition leads to an increase in the densification of the soilcement based mixtures (Fig. 5). As shown in Fig. 7, all soilcement bricks bearing solid waste achieved the requirement of durability $(<10 \%)[16]$ for soil-cement bricks applied as building materials.

\section{CONCLUSIONS}

The following conclusions may be drawn from the experimental results and discussion. Soil-cement bricks have been produced by using solid waste materials (eggshell waste - EW, and welding flux slag waste - WFSW) as renewable raw materials. The solid wastes used in this study are low-cost materials, which behaves as non-plastic charge material and improve the packing and densification of cured soil-cement bricks. The incorporation of solid waste caused several changes on the technical properties and microstructure of the soil-cement bricks. It was found that soil-cement bricks bearing up to $30 \mathrm{wt} \%$ EW (as replacement of Portland cement) and up to $15 \mathrm{wt} \%$ WFSW (as replacement of sandy soil) could serve as building materials. The use of higher concentration of solid waste is not recommended because of the decreased mechanical strength of the soil-cement bricks. The incorporation of EW and WFSW into soil-cement bricks for use as building materials could be an important technical solution in terms of environmental protection and waste management practices.

\section{ACKNOWLEDGEMENTS}

The authors would like to thank CNPq and FAPERJ for the financial support. Authors also would like to thank Aalborg Industries by the supply of welding flux slag waste.

\section{REFERENCES}

[1] M. Safiuddin, M.Z. Jumaat, M.A. Salan, M.S. Islan, R. Hashim, Int. J. Phys. Sci. 5 (2010) 1952-1963.

[2] C. Bones, M.E. Borredon, E. Vedrenne, G. Vilarem, J. Environ. Manag. 143 (2014) 186-196.

[3] W.J. Stadelman, Eggs and eggs products, $2^{\text {nd }}$ Ed., John Wiley, New York, USA (2000).

[4] L. Davis, An introduction to welding fluxes for mild and low alloy steels, The Welding Institute, Cambridge (1981).

[5] R.P.R. Paranhos, A.C. Souza, Soldagem a arco submerso, Rio de Janeiro: SENAI/CEFET de Solda, Rio de Janeiro (1999).

[6] K. Kabiraj, U.K. Mandal, Int. J. Civ. Struct. Eng. 2 (2012) 838-850.

[7] J.L.S.S. Motta, P.W.P. Morais, G.N. Rocha, J.C. Tavares, G.C. Gonçalves, M.A. Chagas, J.L. Mageste, T.P.B. Lucas, e-xacta 7 (2014) 13-26.

[8] A.P.S. Milani, L.C. Labaki, J. Mater. Civ. Eng. 24 (2012) 775-782.

[9] F.B. Siqueira, J.N.F. Holanda, J. Environ. Manag. 131 (2013) 1-6.

[10] J.M. Manso, V. Ortego-López, J.A. Polanco, J. Setién, Constr. Build. Mater. 40 (2013) 126-134.

[11] D.A. Fungaro, M.V. Silva, Am. J. Environ. Protec. 2 (2014) 83-88.

[12] S.V. Ribeiro, J.N.F. Holanda, J. Eng. Sci. Innov. Technol. 3 (2014) 401-408.

[13] M.C. Amaral, F.B. Siqueira, A.Z. Destefani, J.N.F. Holanda, Waste Resour. Manag. 166 (2013) 137-141.

[14] R. A. Bou-Issa, Monografia, UENF-CEMM, Campos dos Goytacazes-RJ (2012).

[15] ABNT, NBR 10836, "Tijolos solo-cimento - Determinação da resistência à compressão e absorção de água", Rio de Janeiro (1994).

[16] ABNT, NBR 13554, "Tijolo solo-cimento: ensaio de durabilidade", Rio de Janeiro (1996).

[17] ABNT, NBR 10834, "Tijolos solo-cimento especificações", Rio de Janeiro (1994).

(Rec. 17/08/2015, Rev. 08/10/2015, 23/11/2015, Ac. 04/03/2016) 